hyperoxia: a dose-response study of lung growth, maturation and changes in anti-oxidant enzyme activities. Pediatr Res 15:999-1008

3. Hayatdavoudi G, O'Neill JJ, Barry BE, Freeman BA, Crapo JD 1981 Pulmonary injury in rats following continuous exposure to $60 \% \mathrm{O}_{2}$ for 7 days. $\mathrm{J}$ Appl Physiol 51:1220-1231

4. Frank L, Bucher JR, Roberts RJ 1979 Oxygen toxicity in neonatal and adult animals of various species. J Appl Physiol 45:699-704

5. Yam J, Frank L, Roberts RJ 1978 Oxygen toxicity: Comparison of lung biochemical responses in neonatal and adult rats. Pediatr Res 12:115-119

6. Marklund S 1979 A simple specific method for the determination of the hemoglobin content of tissue homogenates. Clin Chim Acta 92:229-234

7. Günzler WA, Kremers H, Flohé L 1974 An improved coupled test procedure for glutathione peroxidase (EC 1.11.1.9) in blood. Z Klin Chem Klin Biochem 12:444-448

8. Grankvist K, Marklund SL, Täljedahl I $1981 \mathrm{CuZn-superoxide} \mathrm{dismutase}$ Mn-superoxide dismutase, catalase and glutathione peroxidase in pancreatic islets and other tissues in the mouse. Biochem J 199:393-398

9. Del Rio LA, Ortega MG, Lopez AL, Gorgé JL 1977 A more sensitive modification of the catalase assay with the Clark oxygen electrode. Application to the kinetic study of the pea leaf enzyme. Anal Biochem 80:409-415

10. Marklund S, Marklund G 1974 Involvement of the superoxide anion radical in the autooxidation of pyrogallol and a convenient assay for superoxide dismutase. Eur J Biochem 47:469-474

11. Kissane JM, Robins E 1958 The fluorometric measurement of deoxyribonucleic acid in animal tissues with special reference to the central nervous system. J Biol Chem 233:184-188

12. Hinegardner RT 1971 An improved fluorometric assay for DNA. Anal Biochem 39:197-201

13. Tsuchihashi M 1923 Über die Reinigung der Fumarase. Biochem Z 140:161169

14. Saik LA, Hsiek H, Baricos WH, Shapira E 1982 Enzymatic and immunologic quantitation of erythrocyte superoxide dismutase in adults and in neonates of different gestational ages. Pediatr Res 16:933-937
15. McCord JM, Fridovich I 1969 Superoxide dismutase, an enzymatic function for erythrocuprein (hemocuprein). J Biol Chem 244:6049-6055

16. Yam J, Frank L, Roberts RJ 1978 Age-related development of pulmonary antioxidant enzymes in the rat. Proc Soc Exp Biol Med 157:293-296

17. Roberts RJ 1979 Employment of pulmonary superoxide dismutase, catalase and glutathione peroxidase activity as criteria for assessing suitable animal models for studies of bronchopulmonary dysplasia. J Pediatr 95:904-909

18. Yoshioka T, Motoyama H, Yamasaki F, Noma J 1982 Lipid peroxidation and its protective mechanism during developmental stage in rat. Acta Obstet Gynaecol Jpn 34:966-970

19. Frank L, Groseclose EE 1983 Late gestational changes in lung antioxidant enzymes in fetal rabbit parallel surfactant system changes. Clin Res 31:512A

20. Suttorp N, Gorelich K, Simon LM 1983 Decreased resistance to sustained in vitro hyperoxia related to glutathione peroxidase deficiency in cultivated lung epithelial cells. Clin Res 31:A97

21. Eriksson UJ, Tydén O, Berne C 1983 Glycogen content and lipid biosynthesis in the lungs of fetuses of diabetic rats. Biol Res Pregnancy 4:103-106

22. Maniscalco WM, Wilson CM, Gross I, Gobran L, Rooney SA, Warshaw JB 1978 Development of glycogen and phospholipid metabolism in fetal and newborn rat lung. Biochim Biophys Acta 530:333-346

23. Turrens JF, Freeman BA, Crapo JD 1982 Hyperoxia increases $\mathrm{H}_{2} \mathrm{O}_{2}$ release by lung mitochondria and microsomes. Arch Biochem Biophys 217:411421

24. Frank L, Massaro D 1980 Oxygen toxicity. Am J Med 69:117-126

25. Hoffman M, Stevens SB, Autor AP 1980 Adaption to hyperoxia in the neonatal rat: Kinetic parameters of the oxygen mediated induction of lung superoxide dismutases, catalase and glutathione peroxidase. Toxicology 16:215-225

26. Tanswell AK, Freeman BA 1984 Pulmonary antioxidant enzyme maturation in the fetal and neonatal rat. I. Developmental profiles. Pediatr Res 18:584 587

27. Tanswell AK, Freeman BA 1984 Pulmonary antioxidant enzyme maturation in the fetal and neonatal rat. II. The influence of maternal iron supplements upon fetal lung catalase activity. Pediatr Res 18:871-874

\title{
The Effects of Brain Blood Flow on Brain Bilirubin Deposition in Newborn Piglets
}

\author{
GARY H. BURGESS, WILLIAM OH, DAG BRATLID, ANN-MARI BRUBAKK, \\ WILLIAM J. CASHORE, AND BARBARA S. STONESTREET \\ Department of Pediatrics, Women and Infants Hospital of Rhode Island and The Department of Pediatrics, \\ Brown University Program in Medicine, Providence, Rhode Island 02908
}

\begin{abstract}
Since kernicteric lesions are usually found in the subcortical regions of the brain and these areas also receive the highest blood flow during asphyxia and hypercapnia, we hypothesized that increases in brain bilirubin deposition may be related to increases in brain blood flow. Fourteen piglets underwent a 3-h infusion of bilirubin to maintain total serum bilirubin at approximately $8 \mathrm{mg} / \mathrm{dl}$, during which time blood gases, hemodynamic variables, and brain blood flow were determined. After sacrificing the
\end{abstract}

Received August 30, 1984; accepted March 4, 1985.

Address for reprints Barbara S. Stonestreet, M. Women and Infants Hospital of Rhode Island, 50 Maude Street, Providence, RI 02908

Supported in part by Training Grant 1 T32-HD-07232, National Institute of Child Health and Human Development, Bethesda, MD, and a grant-in-aid from the American Heart Association with funds contributed in part by the Rhode Island affiliate.

D.B. was a recipient of a Fogarty International Fellowship (5-505-TWO289502), Fogarty International Center, Bethesda, MD. A-M.B. was supported by Leiden State University, Leiden, The Netherlands. animals, regional brain bilirubin content was determined. Ten piglets underwent the same protocol; in addition, hypercapnia was induced during the last hour of study $\left(\mathrm{PaCO}_{2}\right.$ approximately $70 \mathrm{~mm} \mathrm{Hg}$ ). The regional brain blood flow and bilirubin deposition were significantly increased over control values $(p<0.05)$ following hypercapnia in the subcortical region and significantly so in the midbrain and cerebellum. In separate groups of control $(n=6)$ and hypercapnia $(n=6)$ piglets, ${ }^{125}$ I-labeled albumin was infused and demonstrated that hypercapnia was not associated with increased regional brain albumin content. We conclude that hypercapnia-induced augmentation in regional brain blood flow is associated with increased deposition of unbound bilirubin. Although the causal relationship between these two observations has not been firmly established, the findings deserve future investigation to clarify the role of brain blood flow, brain bilirubin deposition, and the production of kernicterus in high risk infants. (Pediatr Res 19: 691-696, 1985) 
Kernicterus has been described in low birth weight infants with relatively low levels of serum bilirubin concentration (1-5). Although the reason for this increased risk has been unknown, several hypotheses have been proposed. Blood-brain barrier integrity may differ between full term and low birth weight infants, although some investigators have questioned this concept (6). The reduced serum bilirubin-binding capacity observed in preterm infants may partly account for their increased risk of kernicterus as compared with full-term infants (7). Postmortem examinations of kernicteric infants have revealed regional differences in bilirubin staining. The subcortical areas such as thalamic nuclei, globus pallidus, caudate nucleus, and brainstem have demonstrated more extensive staining than the outer cortex (2, 8-10). Regional differences in brain blood flow have also been demonstrated in several laboratory animals including rats (11), newborn lambs (12), piglets (13), and cats (14). These differences were observed under baseline resting conditions. Furthermore, when challenged with hypercapnia, accentuation of these regional differences were observed both in piglets (13) and in cats (14) with higher blood flow to the subcortical regions than to the cerebrum. In recent studies, we have also demonstrated a flow dependent nature of brain bilirubin deposition (15).

Therefore, on the basis of increased frequency of subcortical staining with bilirubin in kernicteric lesions, the finding that these same regions have marked increases in blood flow during hypercapnia as compared with the cortical regions, and the flowdependent nature of brain bilirubin deposition, we hypothesize that brain bilirubin deposition is augmented by increases in brain blood flow. The purpose of this study was to examine the regional changes in brain blood flow induced by hypercapnia and its relationship to regional brain bilirubin content in newborn piglets.

\section{MATERIALS AND METHODS}

Twenty-four 2- to 4-day old farm-bred piglets were divided into two study groups: a control group $(n=14$, weight $=1.40 \pm$ $0.09 \mathrm{~kg}$, mean $\pm \mathrm{SEM}$ ) in which normocapnia was maintained throughout the study and an experimental group $(n=10$, weight $=1.27 \pm 0.07 \mathrm{~kg}$, mean $\pm \mathrm{SEM}$ ) in which hypercapnia was induced. Within the control group, we performed regional brain blood flow measurements in six piglets and did not in eight in order to assess the potential influence of microsphere injections on the regional brain bilirubin content. As can be seen in Table 1 , we found no difference in regional brain bilirubin contents between the two groups. Thus, the two groups were combined as one control group for data analysis.

Each piglet was removed from its sow on the morning of the study. Surgical procedures were performed under nitrous oxide inhalation anesthesia and local $1 \%$ xylocaine anesthesia. The left ventricle was catheterized via the right brachial artery for radionuclide-labeled microsphere injections using a Sentinel line catheter (inside diameter $0.67 \mathrm{~mm}$, outside diameter $1.05 \mathrm{~mm}$, Argyle, St. Louis, MO); the placement was verified with pressure tracings and by autopsy. Polyvinyl catheters (inside diameter $0.58 \mathrm{~mm}$, outside diameter $0.99 \mathrm{~mm}$, Bolab, Lake Havasu City, AZ) were also inserted into the following: 1) left brachial artery for microsphere reference blood withdrawal, 2) abdominal aorta via the right femoral artery for monitoring heart rate and mean arterial blood pressure and, 3) the inferior vena cava via the right femoral vein for bilirubin and in some animals for ${ }^{125}$ I-labeled albumin infusion. The left common carotid artery was surgically exposed and two strands of 2-0 silk surgical suture were loosely placed behind the artery to allow for rapid access of the artery for catheterization at the termination of the study for in situ brain perfusion. Each piglet was removed from the nitrous oxide and placed in a specially designed darkened box for the study, which permitted access to the catheters without disturbing the piglet.

Following a 1-hr period for stabilization and recovery from
Table 1. Regional brain bilirubin contents in the two control subgroups (mean $\pm S E M$ )

\begin{tabular}{lcc}
\hline & \multicolumn{2}{c}{ Bilirubin content $(\mu \mathrm{g} / \mathrm{g})$} \\
\cline { 2 - 3 } & $\begin{array}{c}\text { Without } \\
\text { microspheres } \\
(n=8)\end{array}$ & $\begin{array}{c}\text { With } \\
\text { microspheres } \\
(n=6)\end{array}$ \\
\hline Cerebrum & $1.6 \pm 0.3$ & $1.8 \pm 0.3$ \\
Thalamus and caudate nucleus & $1.8 \pm 0.4$ & $1.9 \pm 0.4$ \\
Midbrain & $1.8 \pm 0.2$ & $2.5 \pm 0.4$ \\
Cerebellum & $2.1 \pm 0.4$ & $2.1 \pm 0.4$ \\
Brainstem & $2.7 \pm 0.4$ & $2.6 \pm 0.6$ \\
\hline
\end{tabular}

surgery, baseline determinations were made on the awake, unrestrained piglets. Each was then given a 1-min bolus infusion of $12 \mathrm{mg} / \mathrm{kg}$ body weight of unconjugated bovine bilirubin (Sigma Chemical Corp., St. Louis, MO) dissolved in $5.4 \mathrm{ml}$ of a buffered solution. ${ }^{1}$ This was immediately followed by a continuous infusion of $10 \mathrm{mg}$ bilirubin $/ \mathrm{kg} / \mathrm{hr}(167 \mathrm{mg} / 100 \mathrm{ml}$ solution $)$ for 3 $\mathrm{hr}$. Preliminary studies indicated that this bilirubin dose maintained the piglet serum bilirubin at approximately $8 \mathrm{mg} / 100 \mathrm{ml}$ for the duration of the study.

During the study, each control piglet was awake and remained in an enclosed box breathing room air which was provided through portholes in the box walls. In the experimental group, the piglets were made hypercapnic $\left(\mathrm{PaCO}_{2}\right.$ approximately $70 \mathrm{~mm}$ $\mathrm{Hg}$ ) during the last hour of the study by the introduction of a gas mixture of $15 \% \mathrm{CO}_{2}, 21 \% \mathrm{O}_{2}$, and the balance nitrogen through the portholes. Regional brain blood flow was determined at the baseline period, 120 (before hypercapnia), 150, and 180 min of the study period. Regional brain blood flow was measured using the technique described by Heymann et al. (17) with $15 \pm$ $5 \mu \mathrm{m}$ diameter microspheres labeled with one of the following radionuclides: ${ }^{103} \mathrm{Ru},{ }^{57} \mathrm{Co},{ }^{113} \mathrm{Sn},{ }^{46} \mathrm{Sc},{ }^{51} \mathrm{Cr}$, or ${ }^{95} \mathrm{Nb}$ (New England Nuclear, Boston, MA). Approximately $6 \times 10^{5}$ microspheres suspended and continuously agitated in $2 \mathrm{ml}$ of $10 \%$ dextran and $0.01 \%$ Tween were injected within $30 \mathrm{~s}$ into the left ventricle and flushed with $2 \mathrm{ml}$ of normal saline. A reference sample of blood was collected continuously for 2 min beginning $15 \mathrm{~s}$ prior to the microsphere injection, using a constant withdrawal pump (Harvard Apparatus no. 940, Millis, MA) at a rate of $1.03 \mathrm{ml} /$ min. Blood losses due to study sampling were replaced with blood from a young donor piglet. Arterial blood gases (Corning Blood Gas Analyzer 175, Corning Scientific, Medford, MA) were monitored at the baseline period, $60,120,140,160$, and 180 min following the onset of the bilirubin infusion. Mean arterial blood pressure and heart rate were continuously monitored using a pressure transducer (Hewlett-Packard 1280c, Waltham, MA) and recorded on a polygraph (Hewlett-Packard 7754A, Waltham, MA). Hematocrit levels were determined using a microhematocrit method.

At the termination of each study each piglet was anesthetized with nitrous oxide and local $1 \%$ xylocaine in preparation for left carotid artery catheterization with polyvinyl tubing (inside diameter $0.86 \mathrm{~mm}$, outside diameter $1.32 \mathrm{~mm}$, Bolab). The animal was then sacrificed with intravenous sodium thiamylal followed by a solution of saturated potassium chloride. The brain was then perfused in situ via the carotid artery with ice-cold normal saline for $15 \mathrm{~min}$ at a pressure of $60 \mathrm{~mm} \mathrm{Hg}$ in order to remove blood from the brain vasculature and to reduce the breakdown of bilirubin by tissue peroxidases. In order to facilitate the perfusion the superior vena cava was incised, and the descending

\footnotetext{
${ }^{1}$ The buffered solution ( $\mathrm{pH} 7.5$ ) was prepared fresh on the day of each study and consisted of (by volume) 18.5\% $0.1 \mathrm{~N} \mathrm{NaOH}, 44.5 \%$ 5\%-human serum albumin (Armour Pharmaceutical Co. Kankakec, IL), and 37\% $0.055 \mathrm{M}$ phosphate buffer. The bilirubin was first dissolved in the $0.1 \mathrm{~N} \mathrm{NaOH}$ to which the albumin and phosphate buffer solutions were then added. The infusion apparatus containing the bilirubin solution was covered with aluminum foil to prevent light degradation of the bilirubin. This solution has previously been used in our laboratory for bilirubin studies in rats.
} 
aorta was clamped to decrease the retrograde flow around the Circle of Willis and down the contralateral carotid artery. An autopsy was then performed to verify catheter placement and for removal of the brain. The brain was separated from the spinal cord at the level of the first cervical vertebra and divided into right and left hemispheres and weighed. The left hemisphere was divided into approximately 1-g sections representing the following brain regions: brainstem, cerebellum, midbrain, thalamus + caudate nucleus, and cerebrum (four representative sections of cerebrum taken: frontal lobe, occipital lobe, temporal lobe, and parietal lobe). The sections from the left hemisphere were immediately weighed and placed on ice. These sections were assayed within $3 \mathrm{~h}$ of the termination of the study for tissue bilirubin using a modified diazo method following chloroform extraction (18). The right hemisphere was anatomically divided in exactly the same manner as the left and placed into counting vials to an approximate height of $1 \mathrm{~cm}$. Radioactivity of these tissues and of the reference blood samples were measured in a gamma well counter (Packard Autogamma Scintillation Spectrometer, Packard Instruments, Downers Grove, IL). All tissues and blood samples contained a minimum of 400 microspheres. The regional brain blood flow data was calculated, using a computer (PdP-11/34 Digital Equipment Corp, Maynard, MA) to correct for spillovers, according to the formula:

brain blood

flow $=\mathrm{cpm}$ of microspheres in the brain tissue

$(\mathrm{ml} / \mathrm{min}) \quad=\frac{\text { cpm of microspheres in the reference blood }}{\text { chow }}$ $x$ rate of withdrawal
All values for regional brain blood flow were expressed as $\mathrm{ml}$. $\min ^{-1} \cdot 100 \mathrm{~g}^{-1}$. Total serum bilirubin was measured by Martinek's modification of the diazo method of Malloy and Evelyn (19). Serum unbound bilirubin was estimated by the peroxidase method (20). Colorimetric determinations were performed on a single beam spectrophotometer (Gilford model 240, Oberlin, $\mathrm{OH})$ and where appropriate were recorded on an automatic recorder (Gilford model 6051, Oberlin, $\mathrm{OH}$ )

Regional brain albumin content was measured in separate groups of six control and six experimental piglets treated in exactly the same manner as previously described except regional brain blood flow measurements were not determined. Regional brain albumin content was measured by intravenous infusion of $50 \mu \mathrm{Ci}$ of ${ }^{125} \mathrm{I}$-bovine albumin (New England Nuclear) just prior to the bilirubin bolus injection. At the termination of the study, serum was obtained for ${ }^{125}$ I-radioactivity. The serum albumin concentration $(\mathrm{g} / 100 \mathrm{ml})$ at $180 \mathrm{~min}$ was also determined using the bromcresol green spectrophotometric method (20). The specific activity of the serum albumin was calculated:

specific activity (cpm/ $\mu \mathrm{g}$ albumin)

$$
=\frac{\text { serum radioactivity }(\mathrm{cpm} / \mathrm{ml})}{\text { serum albumin concentration }(\mu \mathrm{g} \text { albumin } / \mathrm{ml})}
$$

${ }^{125}$ I-radioactivity of the eight sections of right hemispheric brain tissue as previously described, was determined using the same gamma well counter and corrected to $\mathrm{cpm} / \mathrm{g}$ of brain tissue. The albumin content was then calculated as follows:

\begin{tabular}{|c|c|c|c|c|c|c|c|c|}
\hline & & \multirow[b]{2}{*}{ Baseline } & \multicolumn{3}{|c|}{ Bilirubin infusion } & \multicolumn{3}{|c|}{ Hypercapnia (E group) } \\
\hline & & & 60 & 120 & 140 & 150 & 160 & 180 \\
\hline $\mathrm{pH}$ & $\begin{array}{l}C^{*} \\
E\end{array}$ & $\begin{array}{l}7.47 \pm 0.01 \\
7.42 \pm 0.01 \S\end{array}$ & $\begin{array}{l}7.49 \pm 0.01 \\
7.44 \pm 0.01 \S\end{array}$ & $\begin{array}{l}7.50 \pm 0.01 \dagger \\
7.46 \pm 0.01 \dagger \S\end{array}$ & $\begin{array}{l}7.50 \pm 0.01 \dagger \\
7.17 \pm 0.01 \dagger \S \S\end{array}$ & $\begin{array}{l}\mathrm{ND} \ddagger \\
\mathrm{ND}\end{array}$ & $\begin{array}{l}7.49 \pm 0.01 \\
7.16 \pm 0.01 \dagger \S\end{array}$ & $\begin{array}{l}7.49 \pm 0.01 \dagger(13) \\
7.15 \pm 0.01 \dagger \S\end{array}$ \\
\hline $\mathrm{PACO}_{2}(\mathrm{~mm} \mathrm{Hg})$ & $\begin{array}{l}\mathrm{C} \\
\mathrm{E}\end{array}$ & $\begin{array}{l}35 \pm 1 \\
40 \pm 2 \S\end{array}$ & $\begin{array}{l}33 \pm 1 \\
38 \pm 1 \S\end{array}$ & $\begin{array}{l}32 \pm 1 \dagger \\
36 \pm 1 \S\end{array}$ & $\begin{array}{l}33 \pm 1 \\
70 \pm 1 \dagger \S\end{array}$ & $\begin{array}{l}\text { ND } \\
\text { ND }\end{array}$ & $\begin{array}{l}32 \pm 1 \dagger \\
71 \pm 1 \dagger \S\end{array}$ & $\begin{array}{l}33 \pm 1(13) \\
76 \pm 1+\S\end{array}$ \\
\hline $\mathrm{PAO}_{2}(\mathrm{~mm} \mathrm{Hg})$ & $\begin{array}{l}\mathrm{C} \\
\mathrm{E}\end{array}$ & $\begin{array}{l}75 \pm 3(13) \\
78 \pm 2\end{array}$ & $\begin{array}{l}75 \pm 3(13) \\
80 \pm 2\end{array}$ & $\begin{array}{l}73 \pm 4 \\
81 \pm 2\end{array}$ & $\begin{array}{l}74 \pm 3 \\
117 \pm 3+\S\end{array}$ & $\begin{array}{l}\text { ND } \\
\text { ND }\end{array}$ & $\begin{array}{c}72 \pm 2 \\
117 \pm 3+\S 8\end{array}$ & $\begin{aligned} 71 & \pm 3(13) \\
115 & \pm 3+\S\end{aligned}$ \\
\hline BE (mEq/liter) & $\begin{array}{l}\mathrm{C} \\
\mathrm{E}\end{array}$ & $\begin{array}{l}3 \pm 1 \\
2 \pm 1\end{array}$ & $\begin{array}{l}3 \pm 1 \\
3 \pm 1\end{array}$ & $\begin{array}{l}3 \pm 1 \\
3 \pm 1\end{array}$ & $\begin{array}{c}3 \pm 1 \\
-4 \pm 1 \dagger \S\end{array}$ & $\begin{array}{l}\text { ND } \\
\text { ND }\end{array}$ & $\begin{array}{l}2 \pm 1(13) \\
-4 \pm 1 \dagger \S 8\end{array}$ & $\begin{array}{l}3 \pm 1(13) \\
-3 \pm 1+\S\end{array}$ \\
\hline Heart rate (beats/min) & $\begin{array}{l}\mathrm{C} \\
\mathrm{E}\end{array}$ & $\begin{array}{l}198 \pm 10 \\
(13) \\
194 \pm 6\end{array}$ & $\begin{array}{l}196 \pm 7(12) \\
208 \pm 6(9)\end{array}$ & $\begin{array}{l}209 \pm 7(13) \\
203 \pm 6\end{array}$ & $\begin{array}{l}207 \pm 8(13) \\
221 \pm 15 \dagger(4)\end{array}$ & $\begin{array}{l}210 \pm 7(13) \\
228 \pm 8+\S\end{array}$ & $\begin{array}{l}215 \pm 9 \dagger(13) \\
223 \pm 6 \dagger(4)\end{array}$ & $\begin{array}{l}221 \pm 8 \dagger(13) \\
217 \pm 8 \dagger\end{array}$ \\
\hline $\mathrm{MABP}(\mathrm{mm} \mathrm{Hg})$ & $\begin{array}{l}\mathrm{C} \\
\mathrm{E}\end{array}$ & $\begin{array}{l}69 \pm 3(12) \\
61 \pm 2\end{array}$ & $\begin{array}{l}66 \pm 3(12) \\
67 \pm 2(9)\end{array}$ & $\begin{array}{l}69 \pm 3(12) \\
70 \pm 2 \dagger\end{array}$ & $\begin{array}{l}68 \pm 3(12) \\
67 \pm 4 \dagger(4)\end{array}$ & $\begin{array}{l}71 \pm 3(12) \\
66 \pm 2\end{array}$ & $\begin{array}{l}72 \pm 3(12) \\
62 \pm 3(4)\end{array}$ & $\begin{array}{l}66 \pm 3(12) \\
64 \pm 1\end{array}$ \\
\hline Hematocrit (\%) & $\begin{array}{l}\mathrm{C} \\
\mathrm{E}\end{array}$ & $\begin{array}{l}24 \pm 1 \\
25 \pm 1\end{array}$ & $\begin{array}{l}23 \pm 1 \\
24 \pm 1\end{array}$ & $\begin{array}{l}22 \pm 1 \dagger \\
24 \pm 1\end{array}$ & $\begin{array}{l}\text { ND } \\
\text { ND }\end{array}$ & $\begin{array}{l}\text { ND } \\
\text { ND }\end{array}$ & $\begin{array}{l}\text { ND } \\
\text { ND }\end{array}$ & $\begin{array}{l}22 \pm 1 \dagger(12) \\
23 \pm 1 \dagger\end{array}$ \\
\hline $\begin{array}{l}\text { Total serum bilirubin } \\
(\mathrm{mg} / \mathrm{dl})\end{array}$ & $\begin{array}{l}\mathrm{C} \\
\mathrm{E}\end{array}$ & $\begin{array}{l}1.6 \pm 0.3 \\
0.4 \pm 0.1(8)\end{array}$ & $\begin{array}{l}6.9 \pm 0.3 \dagger \\
7.1 \pm 0.3 \dagger(8)\end{array}$ & $\begin{array}{l}7.9 \pm 0.3 \dagger \\
7.9 \pm 0.5 \dagger\end{array}$ & $\begin{array}{l}\text { ND } \\
\text { ND }\end{array}$ & $\begin{array}{l}8.6 \pm 0.5 \dagger \\
7.5 \pm 0.4 \dagger\end{array}$ & $\begin{array}{l}\text { ND } \\
\text { ND }\end{array}$ & $\begin{array}{l}9.4 \pm 0.4 \dagger \\
8.0 \pm 0.4 \dagger\end{array}$ \\
\hline $\begin{array}{l}\text { Serum unbound bili- } \\
\text { rubin (nmol/liter) }\end{array}$ & $\begin{array}{l}\mathrm{C} \\
\mathrm{E}\end{array}$ & $\begin{array}{l}\text { Not detectable } \\
\text { Not detectable }\end{array}$ & $\begin{array}{l}205 \pm 28 \dagger \\
262 \pm 38 \dagger\end{array}$ & $\begin{array}{l}205 \pm 31 \dagger \\
303 \pm 31 \dagger(9)\end{array}$ & $\begin{array}{l}\text { ND } \\
\text { ND }\end{array}$ & $\begin{array}{l}377 \pm 53 \dagger(13) \\
337 \pm 57 \dagger\end{array}$ & $\begin{array}{l}\text { ND } \\
\text { ND }\end{array}$ & $\begin{array}{l}307 \pm 43 \dagger(13) \\
446 \pm 69 \dagger\end{array}$ \\
\hline Serum albumin $(\mathrm{g} / \mathrm{dl})$ & $\begin{array}{l}\mathrm{C} \\
\mathrm{E}\end{array}$ & $\begin{array}{l}1.4 \pm 0.1 \\
1.1 \pm 0.1 \\
\end{array}$ & $\begin{array}{l}1.5 \pm 0.1 \\
1.3 \pm 0.1 \\
\end{array}$ & $\begin{array}{l}1.6 \pm 0.1 \dagger \\
1.3 \pm 0.1(9)\end{array}$ & $\begin{array}{l}\text { ND } \\
\text { ND }\end{array}$ & $\begin{array}{l}1.7 \pm 0.1 \dagger \\
1.4 \pm 0.1 \dagger \\
\end{array}$ & $\begin{array}{l}\text { ND } \\
\text { ND }\end{array}$ & $\begin{array}{l}1.7 \pm 0.1 \dagger \\
1.5 \pm 0.1 \dagger\end{array}$ \\
\hline
\end{tabular}

Table 2. Arterial blood gas and hemodynamic variables (mean \pm SEM)

${ }^{*} \mathrm{C}$, control group, $n=14$ unless otherwise noted in parentheses. $\mathrm{E}$, experimental group, $n=10$ unless otherwise noted in parentheses.

$\dagger p<0.05$ compared to baseline.

$\ddagger$ Not determined.

$\S p<0.05$ compared to control. 


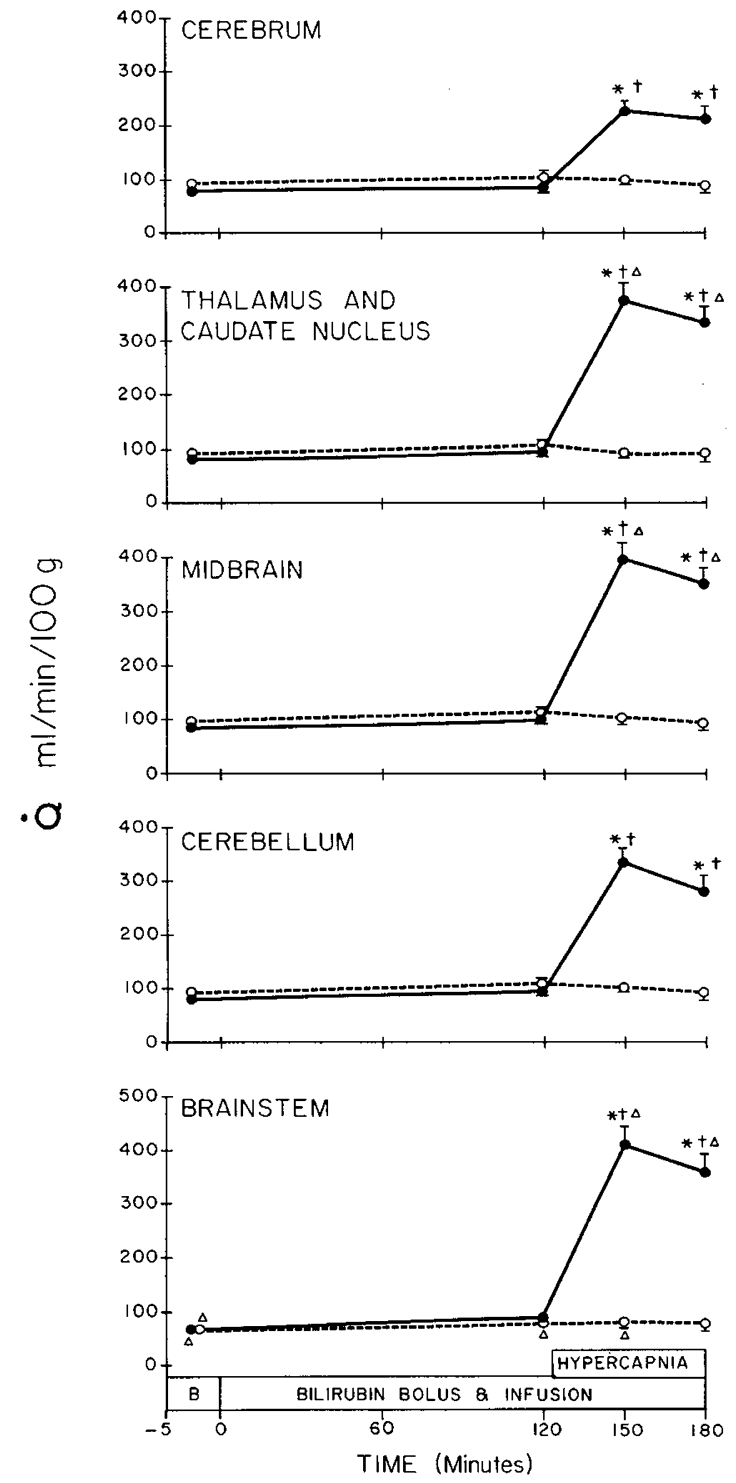

Fig. 1. Regional brain blood flow. Regional brain blood flow versus time ( $B$, baseline) for the control group, open circles $(n=6)$ and the experimental group, closed circles $(n=10)$. All values are expressed as mean \pm SEM. ${ }^{*} p<0.05$ as compared to control, $\uparrow p<0.05$ as compared to baseline with the same group. $\Delta p<0.05$ as compared to cerebrum value during the same time period. brain albumin content ( $\mu \mathrm{g}$ albumin/g brain)

$$
=\frac{\text { brain tissue }{ }^{125} \text { I-radioactivity (cpm/g brain) }}{\text { specific activity of albumin (cpm/ } / \mu \mathrm{g} \text { Albumin) }}
$$

Within group data were compared using the analysis of variance for repetitive measures. Where a significant difference was found, the Dunnett's multiple range $t$ test was used to compare the means to the baseline values (22). Within group regional brain differences were analyzed using analysis of variance and the Newman-Keuls multiple comparison test. Between group analysis was done using the unpaired Student $t$ test; where repetitive measures were compared between groups, the Bonferroni adjustment was used (23). Unless otherwise stated, a $p<$ 0.05 was considered statistically significant. All values were expressed as mean \pm SEM.

\section{RESULTS}

The arterial blood gas values, heart rate, mean arterial blood pressure, hematocrit, total serum bilirubin, serum unbound bilirubin, and serum albumin during the 3-h study in the control and experimental groups are summarized in Table 2 . The $\mathrm{pH}$ and $\mathrm{pCO}_{2}$ values remained stable during the study in the control group. Small differences in these values were observed in the experimental compared to the control group during normocapnia. In the experimental group, during hypercapnia, respiratory acidosis was produced. Heart rates were similar in both groups; increases from baseline values were observed toward the end of the study. Total serum bilirubin, serum unbound bilirubin, and serum albumin values increased similarly from baseline within both groups.

Figure 1 illustrates regional brain blood flow for each brain region examined in the control and experimental groups. Regional brain blood flow remained stable in the control group throughout the study period. In the experimental group, the regional brain blood flows were similar to those of the control group during the normocapnia period. During hypercapnia the blood flow to all brain regions increased significantly above baseline. Furthermore, within the experimental group at 180 min, the blood flow to thalamus + caudate nucleus, midbrain, and brainstem were significantly higher than the blood flow to the cerebrum.

Figure 2 illustrates the regional brain bilirubin content for each brain region examined in the control and experimental groups. Within the control group, the brainstem bilirubin content was significantly higher than the cerebrum. In the experimental group, the bilirubin content in the midbrain and cerebellum was significantly higher than in the control group. Within the exper-

Brain Bilirubin Content

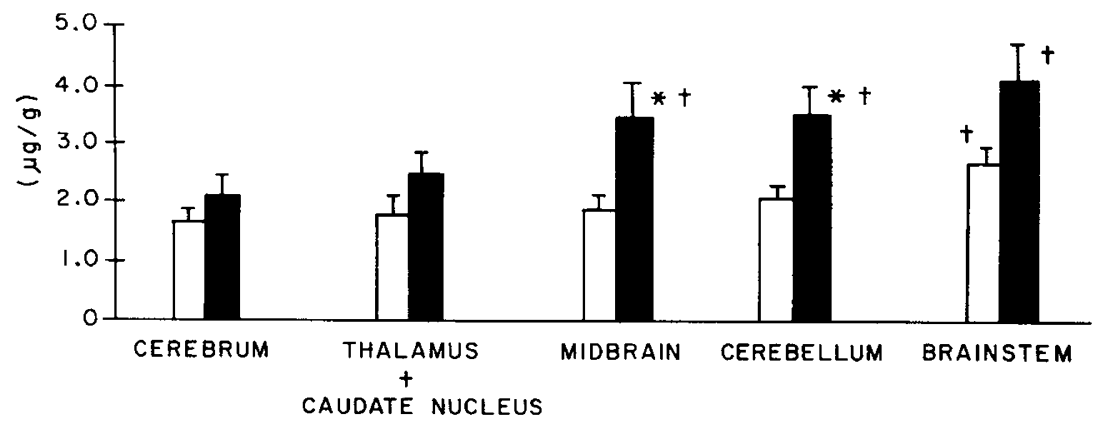

BRAIN REGIONS

Fig. 2. Regional brain bilirubin content. Control group, open bar $(n=14)$ and experimental group, closed bar $(n=10)$. Mean \pm SEM. ${ }^{*} p<0.05$ as compared to control, $\nmid p<0.05$ as compared to the cerebrum value within the same group. 
imental group, the bilirubin content in the midbrain, cerebellum and brainstem was higher than in the cerebrum.

Figure 3 illustrates the regional brain albumin content in all regions examined in the additional groups of control and experimental piglets. The regional brain albumin content did not differ between groups in any region; however, for both the control and experimental groups the cerebellar albumin content was significantly higher than that of the cerebrum $(p<0.05)$.

\section{DISCUSSION}

We utilized the piglet for our study for a number of reasons: 1) cerebral blood flow has been studied in piglets extensively in our laboratory as well as others and regional brain blood flow has been demonstrated to be equal between hemispheres when it is expressed per unit weight of brain tissue $(2,24) ; 2)$ the piglet demonstrated significant increases in regional brain blood flow (13) with hypercapnia; and 3) the size of the piglet's brain provided easy dissection for the regional study of bilirubin content. Although regional brain bilirubin studies have not been done in piglets, several standardized measurements revealed that the modified technique of Bratlid and Winsnes (18) was feasible. The advantage of our surgical preparation was 2-fold: 1) there was minimal instrumentation to the brain itself and 2) the piglet was studied in its awake and intact state.

In preliminary studies, the effect of radionuclide-labeled microspheres on brain bilirubin deposition was examined. The lack of difference in regional brain bilirubin content between the two control subgroups indicated that $6 \times 10^{5}$ radionuclide-labeled microspheres given to these piglets did not alter the regional distribution of brain bilirubin. Furthermore, the results from the control piglets indicated that infusions of our bilirubin solution did not alter regional brain blood flow.

As noted in Table 2 , there was a profound respiratory acidosis induced in the hypercapnic state in the experimental group. The elevation of the $\mathrm{PaO}_{2}$ in the experimental group during hypercapnia may be due to the Bohr effect with a decrease in pH noted during this time period. The heart rate increased during the latter part of the study in both groups; however, 30 min after the induction of hypercapnia the heart rate in the experimental group was significantly higher than the control piglets. The hypercapnia-induced transient increase in heart rate may result from the following possibilities: 1) hypercapnia has been shown to increase cardiac output (25) which is directly related to heart rate (26) and 2) hypercapnia has been shown to increase endogenous catecholamines (27). These results differ slightly from our previous work (13), perhaps because in that study the piglets were pancuronium-paralyzed. There was approximately an $8 \%$ decrease in hematocrit values in both groups despite blood replacement. The change in hematocrit values may have been a dilutional effect of the bilirubin infusion $(6 \mathrm{ml} / \mathrm{kg} / \mathrm{h})$ along with repeated flushing of the catheters with small amounts of normal saline. Although cerebral blood flow is affected by hematocrit values, the hematocrit changes observed in our study were minimal and equivalent in both groups.

Serum total and unbound bilirubin values were maintained in the same range during the study period in both groups. The values obtained for the serum unbound bilirubin in our study group were approximately 10 -fold higher than those obtained in human newborns (7), perhaps in part due to the low serum albumin concentrations found in the newborn piglets. The serum albumin levels in our study piglets increased slightly but significantly from baseline within both groups because of the infusion of human serum albumin throughout the study.

Regional brain blood flow measurements obtained in our piglets agreed with previous work in our laboratory. The experimental piglets had marked increases in brain blood flow to all regions during hypercapnia, and the increases were accentuated in the subcortical areas. Within the control group, the various regions of the brain had similar bilirubin contents, except for a slight but significant increase in bilirubin content in the brainstem as compared to cerebrum. The explanation for the latter observation was not apparent. The bilirubin contents of the various regions in the brain were generally higher during hypercapnia and significantly so in the midbrain and cerebellum (Fig. 2 ). This observation is associated with the increase in regional brain blood flow, but does not firmly establish the cause-effect relationship between blood flow and brain bilirubin deposition. These findings are of interest and deserve future investigation for consideration particularly in regard to the mechanism for such association.

Our study demonstrated no change in regional brain albumin content in the hypercapnia group. This is in contrast to that observed in a rat study in which a 2-fold increase in brain albumin content was found in the rat brains following induction of respiratory acidosis (16). The increased brain albumin content in that study may perhaps be secondary to: 1) the higher $\mathrm{PaCO}_{2}$ values achieved in the rat study cited above $(120$ versus $70 \mathrm{~mm}$ $\mathrm{Hg}$ in our study) and/or 2) possible species differences between rats and piglets. Based on our data, we conclude that the integrity of the blood-brain barrier to albumin in piglets was intact throughout the study and that the bilirubin deposited in the brain probably consisted mostly of unbound bilirubin. There is normally a minute amount of unbound bilirubin present in the circulation and in the brain which is reversibly in constant

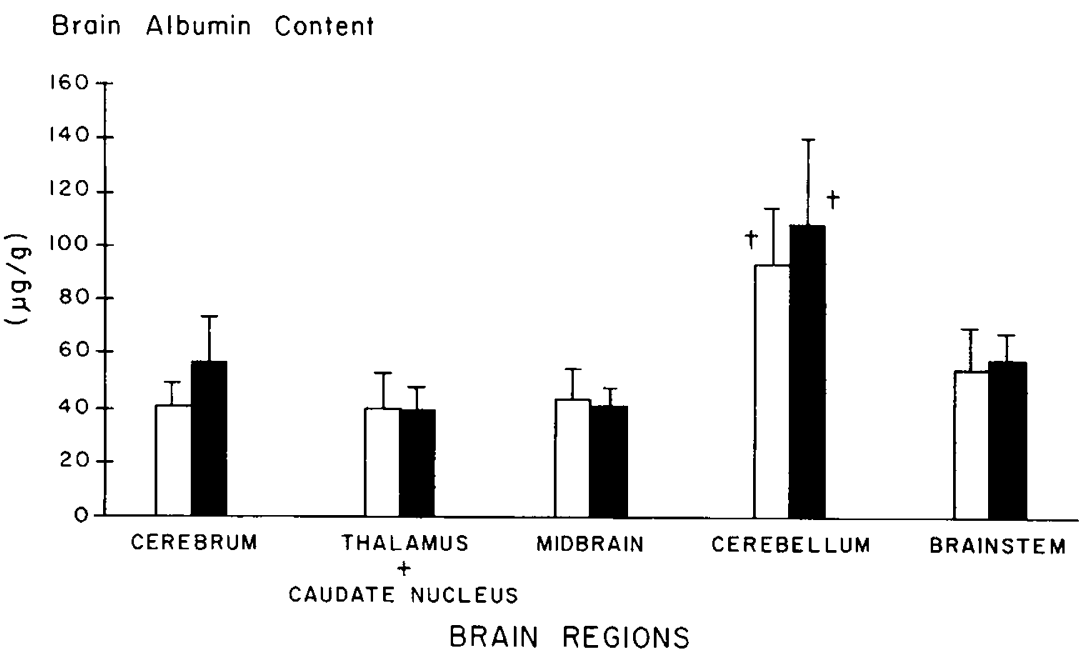

Fig. 3. Regional brain albumin content. Control group, open bar $(n=6)$ and experimental group, closed bar $(n=6)$. Mean \pm SEM. $\dagger p<0.05$ as compared to the cerebrum value within the same group. 
equilibrium between the plasma and brain cellular compartments. We have recently shown that the rate of transfer from the vascular to the tissue compartment (brain) is flow dependent (15).

In summary, hypercapnia in newborn piglets was associated with increased bilirubin deposition which was in part augmented by increased regional brain blood flow. The bilirubin deposited probably consisted primarily of unbound bilirubin, and the integrity of the blood-brain barrier was probably intact to albumin during hypercapnia.

Acknowledgments. The authors acknowledge the excellent technical assistance of Mr. William Macomber, Ms. Carol Calista, and Mr. Steve Warburton. We also thank Freda Volpe for preparation of this manuscript.

\section{REFERENCES}

1. Ackerman BD, Dyer GY, Leydorf MM 1970 Hyperbilirubinemia and kernicterus in small premature infants. Pediatrics 45:918-925

2. Gartner LM, Snyder RN, Chabon RS, Bernstein J 1970 Kernicterus: high incidence in premature infants with low serum bilirubin concentrations. Pediatrics 45:906-917

3. Harris RC, Lucey JF, MacLean RJ 1958 Kernicterus in premature infants associated with low concentration of bilirubin in the plasma. Pediatric 21:875-883

4. Keenan WJ, Perlstein PH, Light IJ, Sutherland JM 1972 Kernicterus in small sick premature infants receiving phototherapy. Pediatrics 49:652-655

5. Stern L, Denton RL 1965 Kernicterus in small premature infants. Pediatrics 35:483-485

6. Wennberg R 1982 Bilirubin transport and toxicity. In: Bilirubin. Mead Johnson Symposium on Perinatal and Developmental Medicine no. 19. Mead Johnson and Co, Evansville, IN, pp 25-31

7. Cashore WJ, Horwich A, Karotkin EH, Oh W 1977 Influence of gestational age and clinical status on bilirubin-binding capacity in newborn infants. Am J Dis Child 131:898-901

8. Ahdab-Barmada M 1983 Neonatal kernicterus: neuropathologic diagnosis. In: Levine RL, Maisels MJ (eds) Hyperbilirubinemia in the Newborn. Report of the Eighty-Fifth Ross Conference on Pediatric Research. Ross Laboratories, Columbus, $\mathrm{OH}$, pp 2-10

9. Kim MH, Yoon JJ, Sher J, Brown AK 1980 Lack of predictive indices in kernicterus: a comparison of clinical and pathologic factors in infants with or without kernicterus. Pediatrics 66:852-858
10. Ritter DA, Kenny JD, Norton HJ, Rudolph AJ 1982 A prospective study of free bilirubin and other risk factors in the development of kernicterus in premature infants. Pediatrics 69:260-266

11. Ohata M, Takei H, Fredericks, WR, Rapaport SI 1982 Effects of immobilization stress on cerebral blood flow and cerebrovascular permeability in spontaneously hypertensive rats. J Cereb Blood Flow Metab 2:373-379

12. Stonestreet BS, Laptook A, Schanler R, Oh W 1981 Hemodynamic responses to asphyxia in spontaneously breathing newborn term and premature lambs. Early Hum Dev 7:81-97

13. Hansen NB, Brubakk AM, Oh W, Bratlid D, Stonestreet BS 1984 The effects of variations in $\mathrm{PaCO}_{2}$ on brain blood flow and cardiac output in the newborn piglet. Pediatr Res 1132-1136

14. Busija DW, Heistad DD 1983 Effects of indomethacin on cerebral blood flow during hypercapnia in cats. Am J Physiol 244 (Heart Circ Physiol 13):H519H524

15. Cashore WJ, Silberberg $M 1984$ Concentration and flow relationships for entry of unbound bilirubin in rat brain. Pediatr Res 18: 314A (abstr)

16. Bratlid D, Cashore WJ, Oh W 1984 Acidosis does not increase bilirubin deposition in rat brain. Pediatrics 73:431-434

17. Heymann MA, Payne BD, Hoffman JIE, Rudolph AM 1977 Blood flow measurements with radionuclide-labelled particles. Prog Cardiovasc Dis 20:55-79

18. Bratlid D, Winsnes A 1971 Determination of conjugated and unconjugated bilirubin methods based on direct spectrophotometry and chloroform extraction. A reappraisal. Scand J Clin Lab Invest 28:41-48

19. Martinek RG 1966 Improved micromethod for determination of serum bilirubin. Clin Chem Acta 13:161-170

20. Jacobsen J, Wennberg RP 1974 Determination of unbound bilirubin in serum of newborns. Clin Chem 20:783-789

21. Doumas BT, Watson WA, Biggs HG 1971 Albumin standards and the measurement of serum albumin with bromcresol green. Clin Chem Acta 31:8796

22. Winer BJ 1971 Single factor experiments having repeated measures on the same elements. In: Maytham W, Shapiro A, Stern J (eds) Statistical Principles in Experimental Design, McGraw-Hill Book Company, New York, pp 261308

23. Wallenstein S, Zucker CL, Fleiss JL 1980 Some statistical methods useful in circulation research. Circ Res 47:1-9

24. Laptook AR, Stonestreet BS, Oh W 1983 The effect of carotid artery ligation on brain blood flow in newborn piglets. Brain Res 276:51-54

25. Anderson MN, Mouritzen C 1966 Effect of acute respiratory and metabolic acidosis on cardiac output and peripheral resistance. Ann Surg 163:161-168

26. Rudolph AM, Heymann MA 1976 Cardiac output in the fetal lamb: the effects of spontaneous and induced changes of heart rate on right and left ventricular output. Am J Obstet Gynecol 124:183-192

27. Nahas GG, Steinsland OS 1968 Increased rate of catecholamine synthesis during respiratory acidosis. Respir Physiol 5:108-117 